\title{
DEVELOPMENT OF PLAYING SKILLS SEPAK TAKRAW EXERCISES MODELS BASED ON INTERACTIVE MULTIMEDIA
}

\author{
Didik Purwanto \\ State University of Tadulako \\ didik_purwanto83@yahoo.com
}

\begin{abstract}
The purpose of this research and development are to developing playing skills sepak takraw exercises models. This research begins with needs analysis using survey method and then developing learning resources with corresponding characteristic with the needs analysis result. The development of playing skills sepak takraw exercises models based on interactive multimedia package in print media form and soft file *exe package in VCD forms. The research method using research method and the development with developing steps design by Borg and Gail. Surely, that method is modifying by the researcher to corresponding with the researcher requirement. The subject of this research is 35 university students who joined Unit Kegiatan Mahasiswa or the student activities unit sepak takraw at Tadulako University. Small group test result obtained percentage of 91,69\% with good category, while the result of large group test obtained percentage 94,16\% with good category, and from exercise data according to the sepak takraw couch this product can be used in the real exercise. Based on effectiveness test result, empirically proven that the product result playing skills sepak takraw exercises models based on interactive multimedia has effectiveness which very good.
\end{abstract}

Key Word : Development, Sepak Takraw Exercises Models, Interactive Multimedia.

The progress technology has been a part of present modern human society. Technology created for simplify human activity. Technology reached all aspect of modern human live, in fact to be society life style including sport world. In coaching world cannot separate from the touch of modern technology. In the history of coaching development, information technology is part of media that used for analysing and convey message to many people, start from print technology a long time ago, like a book that printed, until media telecommunication, recorded sound inside tapes, video, television, computer, mobile phone and internet (e learning).

With the existence of development technology, visual information even nonvisual can be simulated more real and easy to remember by athlete memory in various ways. The use of various learning resource make the usage of technology possible. With the existence of progress technology the athlete will be more easy to get and processing information into a knowledge and realized it into skill with repetition process.

Many advantages obtained of technology usage in the form of multimedia, because multimedia technology can resolve the skill learning difficulties. The purpose of multimedia usage is to resolving space limitation, time, and distance in the training process. Multimedia as learning resource can be part companion from the research process. This research, the researcher has printed book and VCD multimedia interactive as learning resource. The advantage of VCD multimedia interactive choice as learning resource, to understand the speed of learning each athlete, can be patience tutor because it is a program, package in the form Video Compact Disc (VCD) and a book. That can be used by couch when athlete training independently as learning resource anywhere, provide an objective assessment because it given additional evaluation in the form of quiz.

One of media that can be used in the development of training multimedia or study in sepak takraw games with media approach (print and VCD multimedia interactive). The expectation of the existence of exercises interactive multimedia or study will be more effective and efficient so the sport achievement can be maximum even the achievement of control skill playing sepak takraw especially. Sport divided into three scopes, sport education, sport recreation, and sport achievement. 
Inside the law Republic of Indonesia number 3, 2005 on the National Sport System (UU-SKN), article 1, and paragraph 1 explained that "keolahragaan adalah segala aspek yang berkaitan dengan olahraga yang mememerlukan pengaturan, pendidikan, pembelajaran, pembinaan, pengembangan, dan pengawasan". in the process of sportsmanship the science approach and technology has an important role in supporting the progress of national sport, as stated in the National Sports System Act No.3 Year 2005 article 27 paragraph 3, " Bahwa pembinaan dan pengembangan olahraga yang terkait dengan peningkatan prestasi olahraga dilakukan dengan menggunakan pendekatan ilmu pengetahuan dan teknologi yang lebih efektif serta efisien ". According to the law, print and audio-visual media in VCD (Video Compact Disk) form is one of science and effective and efficient technology advantages usage in learning or deepening Sports in demand.

VCD is one of the learning media that can support students to master the exercises material; with this media, a couch can provide explanation that more detailed by stopping certain movements. So athletes can see clearly certain skills, in addition the image and the sound will make athletes more interested to pay attention to the material contained in the VCD, indirectly the goal of training will achieved.

Sepak takraw game is one of the most popular sports by students in Central Sulawesi. In Central Sulawesi, there are three branches of superior sport area covering pencak silat, rowing and sepak takraw. The sepak takraw game becomes one of the sports branches funded by APBN and besides sepak takraw branch is one of sport that developed continuously from activity extracurricular school, UKM University, PPLP and PPLM. Sepak takraw game is one of the unique game.

The couch must maximally facilitate athlete to master sepak takraw skills, either from the phase of cognition, fixation, until the automation. The presentation of the sepak takraw skill exercises model with print media and interactive multimedia VCDs outside of practice hours in a relaxed state expected to help the process of understanding the concept of playing sepak takraw technique. Therefore, in addition to practicing / practice directly in the field could see the impressions model playing sepak takraw skills with print media and interactive multimedia VCD and expected to accelerate the process of mastering playing sepak takraw skill. With the existence of development expected to be able to help socialize sepak takraw to Indonesia society, so in the future will emerge athletes seeds sepak takraw achievement both national and international.

Based on the results of questionnaire preliminary research by researchers to the members of Student Activity Unit (UKM) sepak takraw at Tadulako University obtained the result that 1) from 35 students $100 \%$ of students stated the coach has never provided interactive multimedia to help practice. 2) 35 students $48.57 \%$ of students stated that the model used by trainers is still not varied. 3) From 35 students $100 \%$ stated that there should be development of sepak takraw exercises models, 4) from 35 students $100 \%$ students Felt the need for the development of interactive multimedia sepak takraw skill exercises models. While based on observations by researchers at the time of training, not found any media practice in the form of video or interactive multimedia, and still using the conventional drill model.

To overcome the problems, based on the results of needs analysis, observation, interviews and theoretical studies above, it is necessary to research and development of playing skills sepak takraw exercises models based on interactive multimedia.

\section{Model Development Concept}

The research is an activity or process systematic to solve the problems with the application of the scientific method. Research divided into several forms namely basic research, applied, evaluation, development and urgency. The division of research based on the function and application in education and how long the results used in research and development. Development research finds patterns, sequences growth, changes and especially has intention to develop teaching materials for schools. For examples the development of teaching materials are textbooks, props, training modules and so on. Development research is a research that not used to test theory, but what produced in the test then revised until the results are satisfactory.

Research and Development by Borg \& Gall (1983: 772) is a process used to develop and validate educational products. Meanwhile, according to James Tangkudung (2016: 7) research development is a 
research used to create new products and / or develop existing products based on needs analysis in the field (observation, interview, questionnaire of initial needs). Development according to Setyosari (2015: 277 ) is a process used to develop and to educate educational products, may be processes, products and designs. Another opinion according to Sugiyono (2015: 26) research and development method (R \& D) is a research method used to generate new product design, testing the effectiveness of existing products, and develop and create new products.

The research and development model can be a procedural model, conceptual model, and theoretical model. Procedural model is a descriptive model, which step outlines must be followed to produce the product. The conceptual model is an analytical model that describes the components of the product to develop as well as the interrelationships between the components. Theoretical model is a model that shows the relation of change between events. Further Sukmadinata (2005: 164-165) explains that the products produced from research and development activities are not always in the form of objects or hardware, such as books, modules, learning aids, but can also software, Such as computer programs, classroom learning, libraries or laboratories, or education models, learning, training, guidance, evaluation, management, and so on.

Development model is the result of research oriented to product development result. The model is the one that describes the existence of mind-set, a model usually describes the whole concept of interrelated (Benny, 2009: 86). Sukmadinata (2005: 164) also explains that research and development is a process or steps to develop a new product or refine an existing product, which can accounted.

The Development Model is the basis for developing the product to produce. The development model can be a procedural model, conceptual model, and theoretical model. The procedural model is a descriptive model, indicating to follow the steps to produce the product. The conceptual model is an analytical model, which mentions the product components, analyses detail components and shows the relationships among the components to develop. Theoretical model is a model that draws a framework of thinking based on relevant theories and supported by empirical data. The development research procedure will describe the procedure adopted by the researcher / developer to produce the product (Tim Puslitjaknov, 2008: 8).

Meanwhile, according to Maksum (2012: 79) the purpose of development research is a research to develop a new product or refine existing products. The term product can mean hardware or software. Generally, development research is cycles that stare with the need, the need can complete with product development, and to produce a reliable product needs tested several times.

Therefore, research and development must be doing through the process or steps so that new products or refinement of existing products can be accounted for results and benefits. The research development process is circular starting from the activities of analysis, designing, evaluating and revising until the desired goals.

\section{Definition of Multimedia}

According to opinion by Azhar Arsyad (2011: 170) multimedia is define as more than one medium, it is a combination of text, graphics, animation, sound, and video. The same opinion that expressed by Dina Indriana (2011: 97) multimedia is a messaging system using various types of teaching materials form a unit or package.

While Daryanto (2013: 53) divides multimedia into two categories, namely multimedia linear and interactive multimedia.

"Linear multimedia is a multimedia not equipped with operated user controller. This multimedia runs squarely (sequentially), for example $\mathrm{TV}$ and movies. Interactive multimedia is a multimedia equipped with user-operated controller tools so users can choose what they want for the next process. The examples of interactive multimedia are interactive learning and game applications."

From various opinions above concluded that multimedia is an application device that consists of various media that combined and used to convey messages or information in the learning process

\section{Media Video Compact Disk (VCD)}


Generally, the media is software that contains the message (information) presented be using the equipment. Selection of media should develop corresponding with the goal, the existence of conditions and limitations. An example form of media is video and will be used in this development research. According to Sadiman (2015: 268) Video has a function as a play back device from a program (recording), consisting of at least one or more monitors. The size and type of the tape used for varies video according to need.

The researcher in this development more specialize the use of videodisk, so the skill playing material sepak takraw can be more easy, efficient and effective accepted by the beginner player. In addition to storing image and sound information on the magnetic tape, it also can store the voiced image information on the disc (disk). One of the audio-visual media is Video Compact Disk (VCD). According to Brown (1977: 23) VCD is a medium for distribution or production programs for master programs created in the form of film or video tape and transferred on discs or pieces of plastic through a proper process, formed like a record.

Video CD brief VCD or called View CD or Compact Disc Digital Video is a standard digital format for storing video images in a compact disc. These VCD discs run with a VCD recorder / player. However, almost all types of PC computers, DVD discs / players, and some video game consoles can also run with this type VCD disc.

From various opinions above concluded that VCD media is a complete audio-visual disc-shaped media containing instructional materials that useful for explaining visualized objects, usually having a diameter $12 \mathrm{~cm}$ and projected using a VCD media player.

\section{The Skill of Playing Sepak Takraw}

Sepak takraw is a mixed sport of soccer and volleyball, played on badminton court, and players should not touch the ball with their arms and hands. The most prestigious championship in this branch is the King's Cup World Championships, last time held in Bangkok, Thailand. This game from the 15th century and called Takraw in Thai and Sepak raga in Malay. The ball made from woven rattan and the player stands in circle. In 1940, changed using nets and the number rule (Kurniawan, 2012: 145).

The sepak takraw game played by two teams, the squad team consists of three players. One of the three players called tekong (server) is a player who is in the back of the field. Tekong charged with ball service, receiving, and holding off attack from the opponent squads at the back of the field. Other two players called the right apit and left apit. Both of these players are on the right and left in front of tekong. This player near the net served as ball thrower, receiver and ball blocker from the opponent. Should not step on the line (Armelia, 2008: 12)

From various explanations above, concluded that sepak takraw is a game performed on a rectangular field measuring $13.40 \times 6.10$ meters, and the game performed by two teams, each team three players and one as reserve, And for double event 2 players with one spare player, free field from all obstacles. The field limited by net. The ball made from rattan or plastic (synthetic fiber) woven around. The members use all part of their body in this game, except for the arms and hands. The ball played with returning it to the opponent field over the net. The goal of each player is to return the ball to the opponent's field.

Game activities in sepak takraw are mostly children play activities, the play activities are to master certain skills, it is in learning and training their sepak takraw skill, the skills such as football, service, bait and smash. According to Achmad Sofyan Hanif (2015: 35-43) the basic techniques of sepak takraw include sepak sila, sepak cungkil, sepak badek, sepak cross, memaha, heading, mendada and membahu. Meanwhile, according to Darwis in Winarno (2005: 16) include: (kicking); (2) using front head (forehead), side, and back, (3) using the chest, (4) using the foot, and (5) using the shoulder.

\section{METHOD}

This sepak takraw skills exercises based on interactive multimedia developed by Borg and Gall using steps development as the main model and step development multimedia product by Sutopo. At each 
research stage and this development there are steps design, which the explanation described and modified in according to objectives and conditions of actual research. Here is a development model plan.

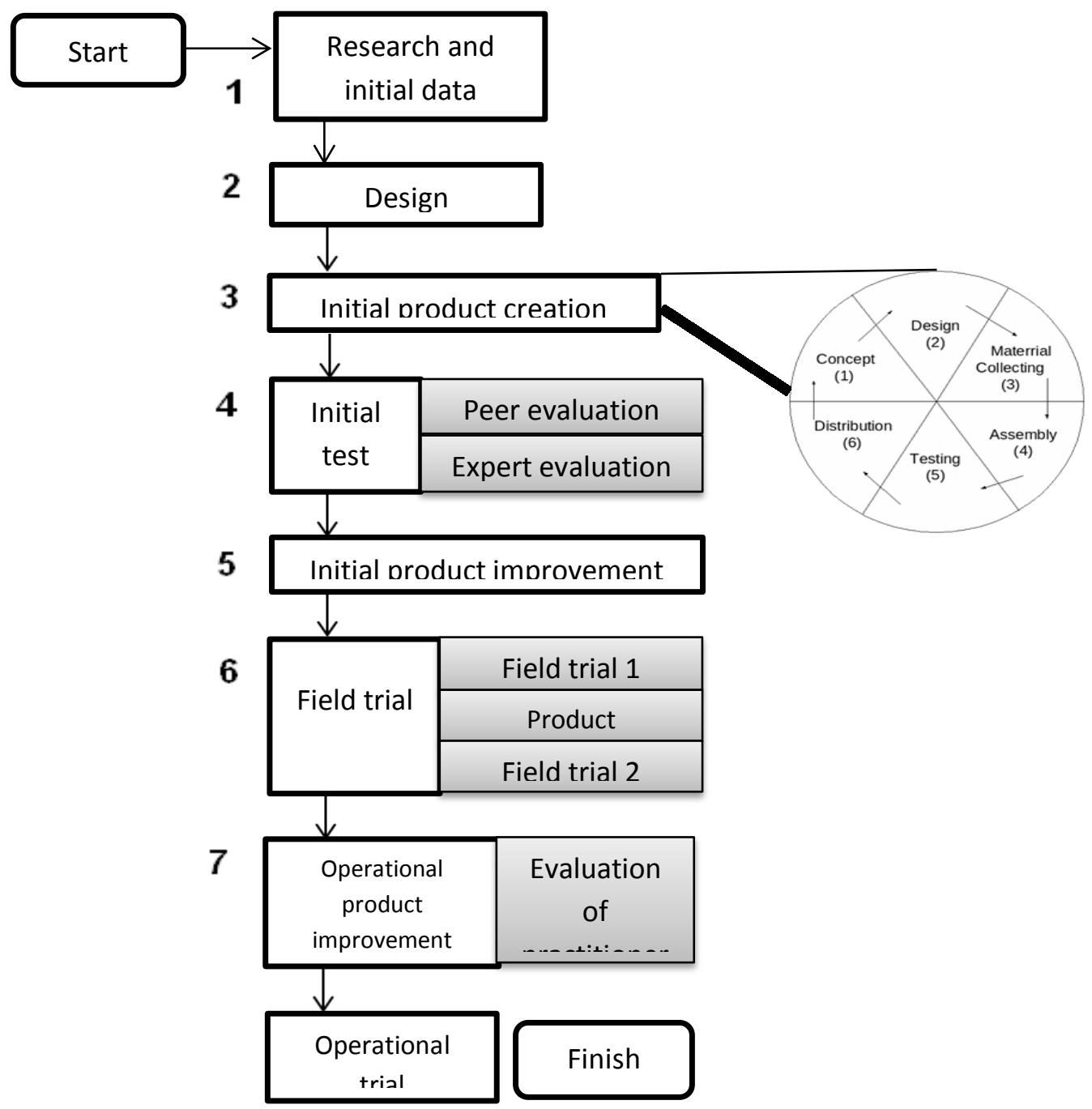

Image of development model plan

The collected research data are quantitative and qualitative data. Therefore, research Instruments use questionnaires, observation sheets, interview guides and documentation. The questionnaire instrument used to obtain validation expert and practitioner, for product trial. Observation Instrument, interview and documentation used only for introduction research. In addition, the research also developed a test instruments sepak takraw skill for testing product effectiveness.

Non-test instruments like questionnaires developed by researchers based on theoretical assessment and consultation counselling to find variables and indicators then became questions data collection related to validation sepak takraw experts, multimedia experts, practitioners, and product trial. Sepak takraw instrument test skills consists of seven tests, which two standardize test and five tests modified by the researcher and contently validated by measurement expert. Research analysis data used quantitative analysis data and experimental analysis pretest-posttest with $\mathrm{T}$ paired sample test to find out the product effectiveness.

\section{RESULT}

From the results of needs analysis, there several key point important to do the development. There are, 1) out of 35 students $100 \%$ of students stated that the trainers had never provided interactive 
multimedia for helping the practice. 2) 35 students $48.57 \%$ of students stated that the model used by trainers was not varied yet 3 ) from 35 students $100 \%$ stated that there needs development of sepak takraw skill models, 4) from 35 students $100 \%$ of students felt the need of development of sepak takraw skill models interactive multimedia.

Initial product of playing skills sepak takraw exercises models based on interactive multimedia consists of 67 exercise models. The developed training model includes ball recognition skills, kicking skills, control skills, service skills, smash skills and block skills.

According to technology study expert evaluation to interactive multimedia development there are four major assessment variables of graphic design, animation and sound effects, the combination of images, sound, video, and ease of use. Based on the data result above interactive multimedia playing skills sepak takraw exercises models completely as good product and can be used.

According to sepak takraw games expert evaluation of development exercises models there are four main valuation variables, the completeness of exercise model, training model accuracy related to sepak takraw skills, description accuracy each model, and video accuracy. Based on the data result presented above obtained model product of sepak takraw skills is feasible to use because it can be do.

From small group trial results, playing skils sepak takraw exercises models based on interactive multimedia obtained from 12 students' responses consisting of 8 main variables: model completeness, model accuracy, description accuracy, video accuracy, graphic design, animation and efficiency, combination of images, sound and video and the ease of use. obtained the score of(X) 29.34 from the maximum score $(\mathrm{Xi}) 32$ which means the average good with the percentage of $91.69 \%$ with good category.

The large group trial results of playing skills sepak takraw exercises models based on interactive multimedia obtained from 40 student responses of UKM Sepak Takraw at Tadulako University consisting of 8 main variables: model completeness, model accuracy, description accuracy, video accuracy, design Graphics, animation and sound effects, combination of images, sound and video and ease of use. Obtained the score of (X) 30.13 from the maximum score (Xi) 32 which means average good with $94.16 \%$ percentage with good category.

The large group trial results of playing skills sepak takraw exercises models based on interactive multimedia obtained from 2 practitioners or sepak takraw couch responses consisting of 8 main variables: model completeness, model accuracy, description accuracy, video accuracy, design graphics, animation and sound effects, combination of images, sound and video, ease of use. Obtained the score of (X) 29.83 of the maximum score (Xi) 32 which means average good with good percentage $93.20 \%$.

Based on the result of calculation data of effectiveness test using paired sample test $\mathrm{T}$ obtained the data.

Table 1 The Result of Paired Sample Test

\section{Paired Samples Test}

\begin{tabular}{|c|c|c|c|c|c|c|c|c|c|}
\hline & & \multicolumn{5}{|c|}{ Paired Differences } & \multirow[b]{3}{*}{$\mathrm{T}$} & \multirow[b]{3}{*}{ df } & \multirow{3}{*}{$\begin{array}{l}\text { Sig. (2- } \\
\text { tailed) }\end{array}$} \\
\hline & & \multirow[b]{2}{*}{ Mean } & \multirow{2}{*}{$\begin{array}{c}\text { Std. } \\
\text { Deviation }\end{array}$} & \multirow{2}{*}{$\begin{array}{l}\text { Std. } \\
\text { Error } \\
\text { Mean }\end{array}$} & \multicolumn{2}{|c|}{$\begin{array}{l}95 \% \text { Confidence } \\
\text { Interval of the } \\
\text { Difference }\end{array}$} & & & \\
\hline & & & & & Lower & Upper & & & \\
\hline $\begin{array}{l}\text { Pair } \\
1\end{array}$ & $\begin{array}{l}\text { Posttest - } \\
\text { Pretest }\end{array}$ & 4.98000 & 8.00385 & 1.26552 & 47.24025 & 52.35975 & 39.351 & 39 & .000 \\
\hline
\end{tabular}

The influence significance test with SPSS 21 got mean $=4,98000$ show difference of pre-test and post-test, count result $=39,351, \mathrm{df}=39$ and significance level $0,00<0,05$ its mean there is influence 
significant between before and After the treatment of playing skills sepak takraw exercises models based on interactive multimedia.

The diagram below illustrates the average result comparatives of overall test record sepak takraw skill before and after the application of playing skills sepak takraw exercises models based on interactive multimedia.

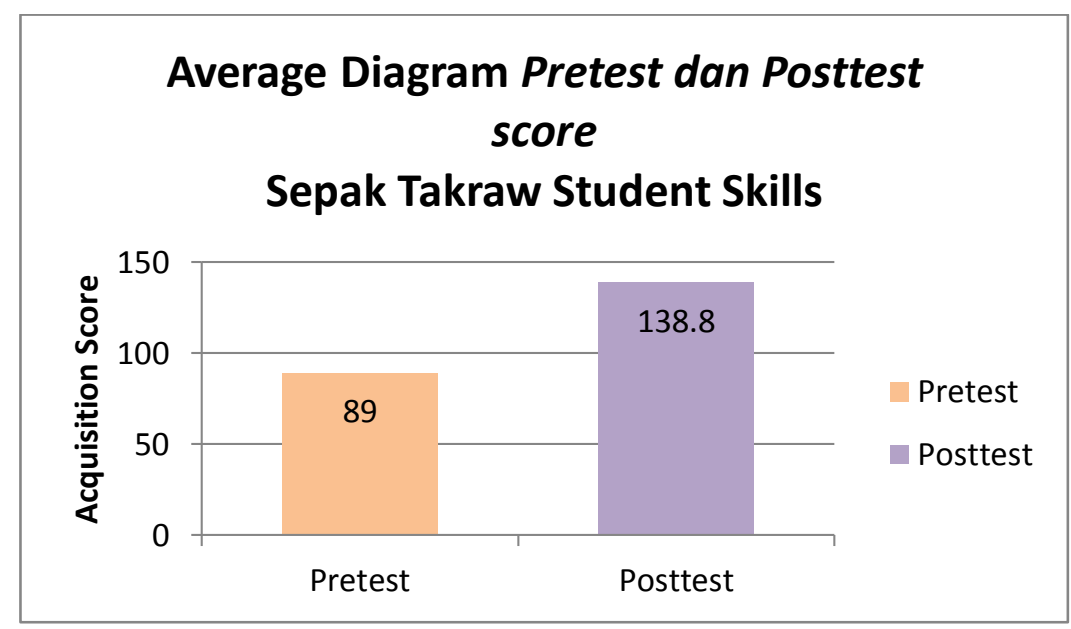

\section{CONCLUSIONS}

that:

Based on data obtained, from the field trials results and discussion of research results concluded

With this playing skills sepak takraw exercises models based on interactive multimedia students learn and train effectively and efficiently. With the material of playing skills sepak takraw exercises models based on interactive multimedia that developed by the researcher, the student can master the theory and practice playing skills sepak takraw quickly and correctly.Implementation of playing skills sepak takraw exercises models based on interactive multimedia demands the structure and direct learning according to learning objectives and even training of development of cognitive student and athlete skills. Generally, this exercises models based on interactive can studied independently through video tutorials. Although the test results and validation tests show that playing skills sepak takraw exercises models based on interactive multimedia is quite good result, but in the preparation exercises material stage or teaching materials seem still difficult especially controlling studies or student skill exercises. Exercises models should utilize properly with the implementation of playing skill sepak takraw exercises skills based on in interactive multimedia.

\section{REFERENCES}

Achmad Sofyan Hanif. Sepaktakraw untuk Pelajar. Jakarta: PT Raja Grafindo Persada, 2015.

Azhar Arsyad. Media Pembelajaran.Jakarta: Raja Grafindo Persada, 2011.

Armelia F. Bermain Sepak Takraw. Semarang: PT Aneka Ilmu, 2008.

Ali, Maksum. Metodologi Penelitian dalam Olahraga. Surabaya: Unesa University Press, 2012.

Benny A. Pribadi. Model Desain Sistem Pembelajaran. Jakarta: PT. Dian Rakyat, 2009.

Brown, James. W.. AV Instruction, Technology, Media and Methods. New York: Mc Graw Hill, 1977.

Daryanto. Media Pembelajaran. Yogyakarta: Gava Media, 2013.

Dina Indriana. Ragam Alat Bantu Media Pengajaran. Yogyakarta: DIVA Press, 2011.

Feri Kurniawan. Buku Pintar Pengetahuan Olahraga. Jakarta: Niaga Swadaya, 2012.

James Tangkudung, Macam-Macam Metodologi Penelitian Uraian dan Contohnya Jakarta : Lensa Media Pustaka, 2016.

Setyosari, Punaji. Metode Penelitian Pendidikan dan Pengembangan. Jakarta: Prenamedia Group, 2015. Sugiyono. Metode Penelitian \& Pengembangan Research and Development. Bandung: Alfabeta, 2015. 
Undang-Undang Nomor 3 tahun 2005 tentang Sistem Keolahragaan Nasional.

Walter R. Borg and Meredith D. Gall. Educational Research: An Introduction, 4th Edition. New York: Longman Inc., 1983.

Winarno, M.E. Pengembangan Permainan Sepaktakraw. Malang: Universitas Negeri Malang, 2004. 